\title{
Survival of 'atypical' Aeromonas salmonicida in water and sediment microcosms of different salinities and temperatures
}

\author{
Tom Wiklund
}

Institute of Parasitology, Åbo Akademi University, BioCity, Artillerigatan 6, FIN-20520 Åbo, Finland

\begin{abstract}
The survival of 'atypical', cytochrome oxidase-negative Aeromonas salmonicida in microcosms containing sterilized water and sediment was assessed using the plate count method. The effect of salinity, temperature and presence of sediment was investigated on the survival of 2 strains isolated from ulcerated flounder Platichthys flesus from the northern Baltic Sea. The strains survived for only a short period $(<14 \mathrm{~d})$ when inoculated into microcosms containing only sterilized brackish water $(S=6.4$ $\pm 0.5 \%$ ). When sterile sediment was added to the microcosms containing brackish water, the inoculated strains survived for up to $63 \mathrm{~d}$. In microcosms with sterile sediment and fresh water or salt water $(\mathrm{S}=$ $30 \%$ ), the strains survived for a considerably shorter period than in microcosms containing sterile brackish water and sediment. In sterilized water, the strains showed a better survival at $4^{\circ} \mathrm{C}$ than at $15^{\circ} \mathrm{C}$. In water and sediment, a slightly increased survival occurred at $15^{\circ} \mathrm{C}$. Adding nutrients (peptone) to the microcosms, when bacteria no longer were recovered by culture methods, did not resuscitate possible non-culturable or dormant cells. These results suggest that 'atypical' A salmonicida, shed from ulcers of diseased flounders, may survive in the bottom sediment of brackish water environments for a long time. The sediment can thus act as a reservoir for this pathogen, facilitating the spread of the disease.
\end{abstract}

KEY WORDS: 'Atypical' Aeromonas salmonicida - Ulcer disease · Flounder · Platichthys flesus · Survival

\section{INTRODUCTION}

'Typical' Aeromonas salmonicida (subsp. salmonicida) was originally described as the causative agent of furunculosis in salmonid fish. 'Atypical' A. salmonicida, i.e. strains of $A$. salmonicida not included in the subspecies salmonicida, has been isolated from diseased fish of a variety of species (Evelyn 1971, Bootsma et al. 1977, Shotts et al, 1980, Cornick et al. 1984, Ohtsuka et al. 1984, Kitao et al. 1985, Böhm et al. 1986, Dalsgaard \& Paulsen 1986, Traxler \& Bell 1988, Wiklund 1990, Wiklund \& Bylund 1991). The disease caused by the atypical strains is, in many cases, characterized by superficial skin ulcers (Bootsma et al. 1977, Shotts et al. 1980, Kitao et al. 1985, Wichardt et al. 1989, Wiklund 1990, Wiklund \& Bylund 1991). 'Atypical' A. salmonicida can, in some cases, be isolated only from the superficial lesions (Wiklund 1990 , Wiklund \& Bylund 1991). The transmission of the pathogen may occur directly from diseased fish to healthy specimens or, alternatively, the bacteria can be released into the water and sediment with subsequent infection of the skin of healthy fish. The survival of cells released into the water is important when considering the epizootiology of the infection. Also the possibility that 'atypical' $A$. salmonicida may constitute a part of the normal bacterial flora of the water has to be taken into consideration.

Skin ulceration is a common disease of flounder Platichthys flesus (L.) in the coastal waters of the Baltic Sea and the North Sea (Möller 1990, Vethaak 1992, Wiklund \& Bylund 1993). 'Atypical' Aeromonas salmonicida has been isolated from ulcerated flounders from the northern and southern Baltic Sea (Wiklund \& Bylund 1991, Wiklund et al. 1994), and from the Danish coast of the North Sea (author's unpubl, results). Unlike most other 'atypicals', these 'atypical' A. salmonicida strains show a negative reaction in the cytochrome oxidase test (Wiklund \& Bylund 1991, Wiklund et al. 1994). 
Sources and routes of infection involved in ulcer disease of flounder still remain unclear. In order to explain the etiology of the disease, there is a need to understand the factors influencing survival of the pathogen in the environment.

In the case of furunculosis, caused by 'typical' Aeromonas salmonicida, it has been established that infected fish shed the pathogen into the environment (Enger et al. 1992). The survival of the bacterium in water, sediment and dead fish has been examined in several studies (Cornick et al. 1969, McCarthy 1977. Michel \& Dubois-Darnaudpeys 1980, Allen-Austin et al. 1984, Sakai 1986, Rose et al. 1990, Morgan et al. 1991). However, there is only 1 report of a similar study on 'atypical' A. salmonicida (Evelyn 1971).

The aim of the present study was to examine the survival of 'atypical', oxidase-negative Aeromonas salmonicida strains, isolated from flounder, under different environmental conditions.

\section{MATERIALS AND METHODS}

Experimental design. Three experiments were performed to examine the survival of 'atypical', cytochrome oxidase-negative Aeromonas salmonicida strains under different environmental conditions. The survival was tested in microcosms containing only sterilized (autoclaved, $120^{\circ} \mathrm{C}, 15 \mathrm{~min}$ ) water or sterilized water and sediment.

In the first experiment the survival of the bacteria was tested in sterilized brackish water without sediment. In the second experiment, the effect of 2 different sterilized sediments on the survival of the bacteria was tested. In the third experiment, the effect of salinity on the survival of the bacteria was tested in sterilized fresh, brackish and salt water containing sterilized 'natural' sediment. All experiments were performed in duplicate.

Microcosms. Microcosms were prepared using $100 \mathrm{ml}$ Erlenmeyer flasks (metal cap) containing $50 \mathrm{ml}$ of autoclaved water and, in 2 of the experiments, $25 \mathrm{~g}$ of autoclaved sediment. The microcosms were incubated in water baths with constant agitation.

Water. The fresh water was collected from Lake Littoistenjärvi, SW Finland. The brackish water ( $\mathrm{S}=6.4 \pm$ $0.5 \%$ after sterilization) used in all experiments was taken from the Archipelago Sea, SW Finland. The salt water was made from brackish water supplemented with chemically defined sea salt (Natura Sea Salt) and adjusted to $30 \%$. The salinity of the different waters was measured with a salinometer. The $\mathrm{pH}$ of the waters was adjusted to 7.0 with $\mathrm{HCl}$ before autoclaving. After autoclaving, the $\mathrm{pH}$ varied from 7.2 to 7.5
Sediment. Two different sediments were used, 'natural' and 'refined'. The 'natural' sediment was collected from the shore of a sand beach on the south coast of Finland (Hangö). The 'refined' sediment was obtained from Merck (Seesand). It consisted of sand particles, which, according to the manufacturer, had been treated with acid and heat. Both sediments were washed 10 times with the appropriate water in order to stabilize the salinity. Care was taken not to wash away solid particles from the sediment. All sediments were sterilized together with the water in the microcosms by autoclaving.

Temperatures. Each experiment was performed at 2 temperatures $\left(4^{\circ} \mathrm{C}\right.$ and $\left.15^{\circ} \mathrm{C}\right)$.

Bacterial strains. The strains used (26F25-20 and 5F9-6/A) were isolated from ulcers of diseased flounder from the northern Baltic Sea. The strains were identified as 'atypical', cytochrome oxidase-negative Aeromonas salmonicida (Wiklund \& Bylund 1991, Wiklund et al. 1994). They were stored at $-70^{\circ} \mathrm{C}$ in brain heart infusion broth (BHI, Difco) supplemented with 5\% newborn calf serum (NCS, Gibco) and $12 \%$ glycerol.

Inoculum. The strains were incubated in BHI and $5 \% \mathrm{NCS}$ for $40 \mathrm{~h}$ at $20^{\circ} \mathrm{C}$. The cells were collected at $1500 \times g$ and washed twice with sterile $0.9 \% \mathrm{NaCl}$. The final cell pellet was resuspended in $0.9 \% \mathrm{NaCl}$ and used as inoculum. The cell number of the inoculum was determined by plating 10 -fold serial dilutions on agar (BHI agar $+5 \%$ NCS) and counting the resulting colonies. The cell count was expressed as colony-forming units (CFU). A volume of $0.5 \mathrm{ml}$ of the inoculum was aseptically added to the microcosms, which were immediately transferred to their respective water baths.

Recovery of the bacteria. Before sampling, the microcosms were shaken to disperse the bacteria in the water. For the enumeration of bacteria, $1 \mathrm{ml}$ of water was taken from the microcosms at selected time intervals until no viable bacteria were recovered on 2 consecutive sampling dates. The samples were diluted 10 fold in sterile $0.9 \%$ saline and 5 separate $10 \mu \mathrm{l}$ drops (Plumb \& Quinlan 1986) of each dilution were plated on BHI agar supplemented with $5 \%$ NCS. When the number of the viable cells in the microcosms dropped below $100 \mathrm{CFU} \mathrm{ml} \mathrm{ml}^{-1}, 100 \mu \mathrm{l}$, instead of $10 \mu \mathrm{l}$, of the inoculated water was seeded on 1 agar plate. The agar plates were incubated at $20^{\circ} \mathrm{C}$ for $7 \mathrm{~d}$. The identification of 'atypical' Aeromonas salmonicida was mainly based on the morphology, color and growth characteristics of the colonies. In doubtful cases, the identification was confirmed on the basis of Gram reaction, cytochrome reaction, motility, and oxidative/fermentative reaction.

When bacteria were no longer recovered on agar plates or when the number of bacteria recovered on 
the agar plates rapidly decreased, $1 \mathrm{ml}$ of the experimental water was inoculated into tubes containing $\mathrm{BHI}$ broth (supplemented with 5\% NCS). The tubes were incubated at $20^{\circ} \mathrm{C}$ for $7 \mathrm{~d}$. Growth of bacteria in the broth was confirmed by subsequent seeding on an agar plate. The bacteria recovered from broth cultures were identified on the basis of colony morphology, oxidase reaction, motility, and oxidative/fermentative reaction.

Revival studies. In the experiment with different sediments, tests were performed to determine whether dormant cells were present in the microcosms. After $11 \mathrm{wk}$ of incubation of the microcosms, when bacteria were no longer recovered on agar plates or in broth, peptone (Difco) was added to most microcosms to a final concentration of $0.01 \%$, in order to resuscitate any dormant cells. Peptone was not added to 2 of the microcosms accidentally contaminated with unidentified bacteria (see later). One week after the addition of peptone, $1 \mathrm{ml}$ of the experiment water was inoculated into BHI (+ $5 \%$ NCS) broth tubes which were then treated as previously described.

Calculation and presentation of the results. Bacterial numbers in the microcosms were calculated, when possible, from the dilution that gave between 3 and 30 colonies on the agar plates. The bacterial numbers are expressed as an average of the bacterial numbers in the 2 parallel microcosms.

\section{RESULTS}

\section{Survival of bacteria in sterile brackish water}

The experiment with microcosms containing sterile brackish water without sediment showed that survival ranged from 1 to $7 \mathrm{~d}$, depending on the strain and the temperature (Fig. 1). Strain 5F29-6/A showed a better survival than strain $26 \mathrm{~F} 25-20$ at both temperatures tested $\left(4\right.$ and $15^{\circ} \mathrm{C}$ )

\section{Effect of sterile sediment on viability}

The inclusion of sterile 'natural' sediment to the microcosms containing sterile brackish water markedly prolonged survival of the bacteria at both temperatures (Fig. 2A, B). In the experiment with sterile water of different salinities (Fig. 3), both strains were viable in the microcosms containing brackish water and sediment at both temperatures after $35 \mathrm{~d}$ of incubation, at which time the experiment was terminated. In the experiment investigating the difference between 2 different sediments on the survival rate, strain $26 \mathrm{~F} 25$ 20 was not recovered with the plate count method after 29 d at $4^{\circ} \mathrm{C}$ from the microcosms containing 'natural' sediment (Fig. 2). But, after inoculating $1 \mathrm{ml}$ of the water into BHI broth, viable cells were recovered for up to $42 \mathrm{~d}$ of incubation in the microcosms (Table 1). In the microcosms with sterile 'refined' sand, no viable bacteria were detected either with the plate count method or with broth tube inoculation after $29 \mathrm{~d}$ of incubation at the temperatures tested (Fig. 2, Table 1).

\section{Effect of temperature on viability}

Low temperature extended the survival time for both strains when inoculated into microcosms containing only sterile brackish water (Fig. 1). When the strains were inoculated into water with sediment (Expts 2 and $3)$, a higher temperature seemed to be more beneficial (Figs. 2 \& 3).
Fig. 1. Aeromonas salmonicida. Survival of 'atypical', cytochrome oxidasenegative strain 26F25-20 (Strain 26) and strain 5F29-6/A (Strain 5) in microcosms with sterile brackish water at $4^{\circ} \mathrm{C}$ and $15^{\circ} \mathrm{C}$

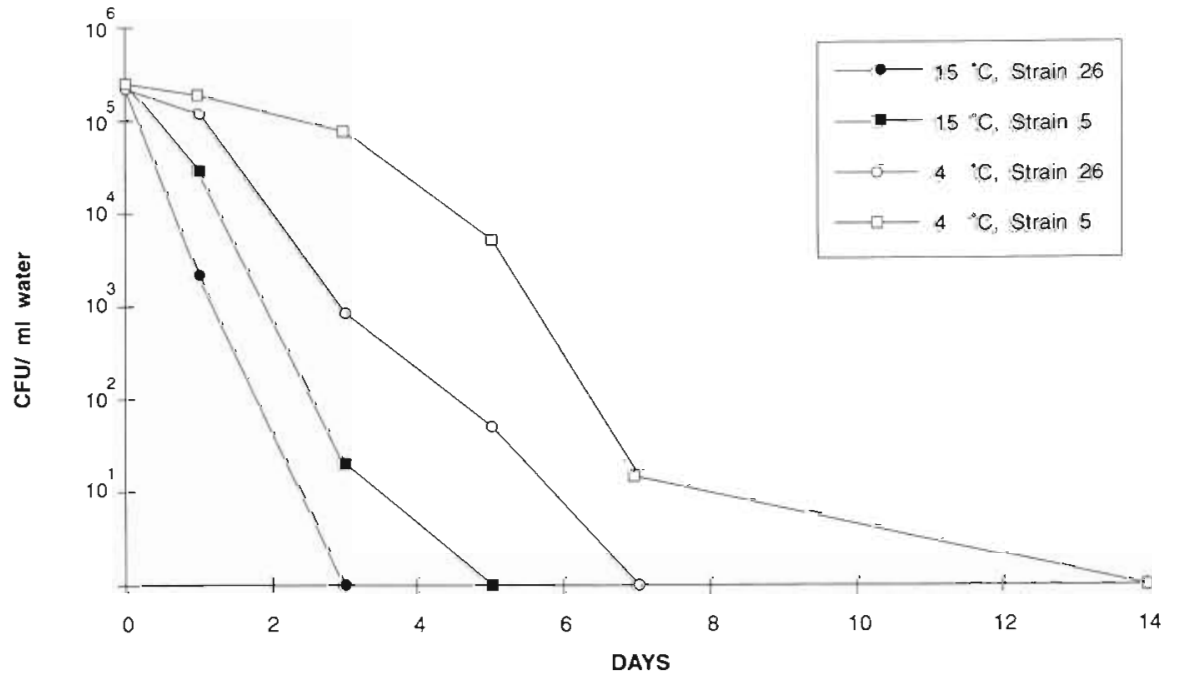


Table 1. Aeromonas salmonicida. Recovery (days after inoculation) on agar plates and in broth culture of cells of 2 'atypical', cytochrome oxidase-negative strains inoculated into microcosms ( $\mathrm{n}=2$ ) containing sterile brackish water and sterile 'natural' or 'refined' sediment

\begin{tabular}{|c|c|c|c|c|}
\hline \multirow[t]{2}{*}{ Temperature } & \multirow[t]{2}{*}{ Strain } & \multirow[t]{2}{*}{ Sediment } & \multicolumn{2}{|c|}{ Recovery on/in: } \\
\hline & & & Plate (d) & Broth (d) \\
\hline $4^{\circ} \mathrm{C}$ & $5 F 29-6 / A$ & 'Natural' & 42 & 42 \\
\hline $4^{\circ} \mathrm{C}$ & $26 F 25-20$ & 'Natural' & 29 & 42 \\
\hline $4^{\circ} \mathrm{C}$ & $5 F 29-6 / A$ & 'Refined' & 14 & 14 \\
\hline $4^{\circ} \mathrm{C}$ & $26 \mathrm{~F} 25-20$ & 'Refined' & 14 & 29 \\
\hline $15^{\circ} \mathrm{C}$ & $5 F 29-6 / A$ & 'Natural' & 63 & 63 \\
\hline $15^{\circ} \mathrm{C}$ & $26 \mathrm{~F} 25-20$ & 'Natural' & 42 & $49^{\circ}$ \\
\hline $15^{\circ} \mathrm{C}$ & $5 F 29-6 / A$ & 'Refined' & 21 & 21 \\
\hline $15^{\circ} \mathrm{C}$ & $26 \mathrm{~F} 25-20$ & 'Refined' & 21 & $29^{\circ}$ \\
\hline $\begin{array}{l}\text {-One micro } \\
\text { contamina }\end{array}$ & $\begin{array}{l}\text { osm only: } \\
\text { ed with un }\end{array}$ & $\begin{array}{l}\text { duplicate } \\
\text { wn bacte }\end{array}$ & licrocosm & was \\
\hline
\end{tabular}

\section{Effect of salinity on viability}

The survival patterns of the 2 strains, inoculated into microcosms with sterile sediment and sterile fresh, brackish and salt water, are shown in Fig. 3. From the microcosms with sediment and fresh water viable bacteria were detected for up to 7 and $14 \mathrm{~d}$ of incubation, respectively. The bacteria in the microcosms with salt water could be recovered for up to 14 and $28 \mathrm{~d}$ post inoculation. The bacteria in the microcosms with brackish water were still viable when the experiment was terminated after $35 \mathrm{~d}$.

\section{Difierences between the 2 strains tested}

Strain 26F25-20 showed a better survival than strain 5F29-6/A only in the experiment with fresh water (Expt 3) at $4^{\circ} \mathrm{C}$ (Fig. 3). In all other experiments either the strain 5F29-6/A showed a better survival or there were no clear differences recorded between the 2 strains (Figs. 1, 2 \& 3).

\section{Revival studies}

The addition of peptone to the microcosms in the experiment with different sediments did not resuscitate possible dormant cells.
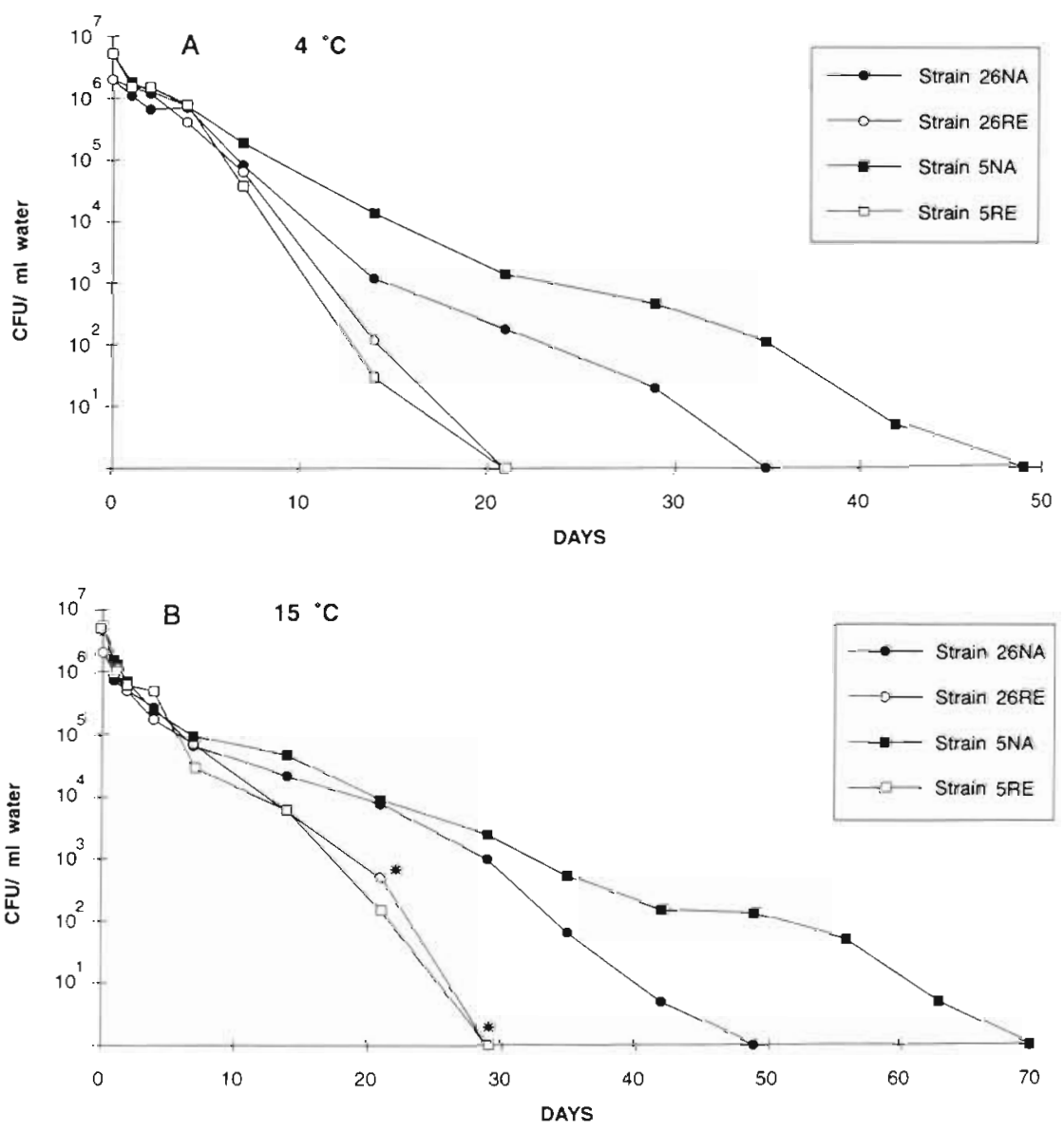

Fig. 2. Aeromonas salmonicida. Survival of 'atypical', cytochrome oxidase-negative strain 26F25-20 (Strain 26) and strain 5F29-6/A (Strain 5) in microcosms with sterile brackish water and sterile 'natural' sediment (NA) and sterile 'refined' sediment (RE) at (A) $4^{\circ} \mathrm{C}$ and (B) $15^{\circ} \mathrm{C}$. 'One microcosm was contaminated with unknown bacterla 
Fig. 3. Aeromonas salmonicida. Survival of 'atypical', cytochrome oxidasenegative A. salmonicida strain 26F2520 (Strain 26) and strain 5F29-6/A (Strain 5) in microcosms with sterile fresh water (FR), brackish water (BR) and salt water (SA) at (A) $4^{\circ} \mathrm{C}$ and (B) $15^{\circ} \mathrm{C}$. . One microcosm was contaminated with unknown bacteria
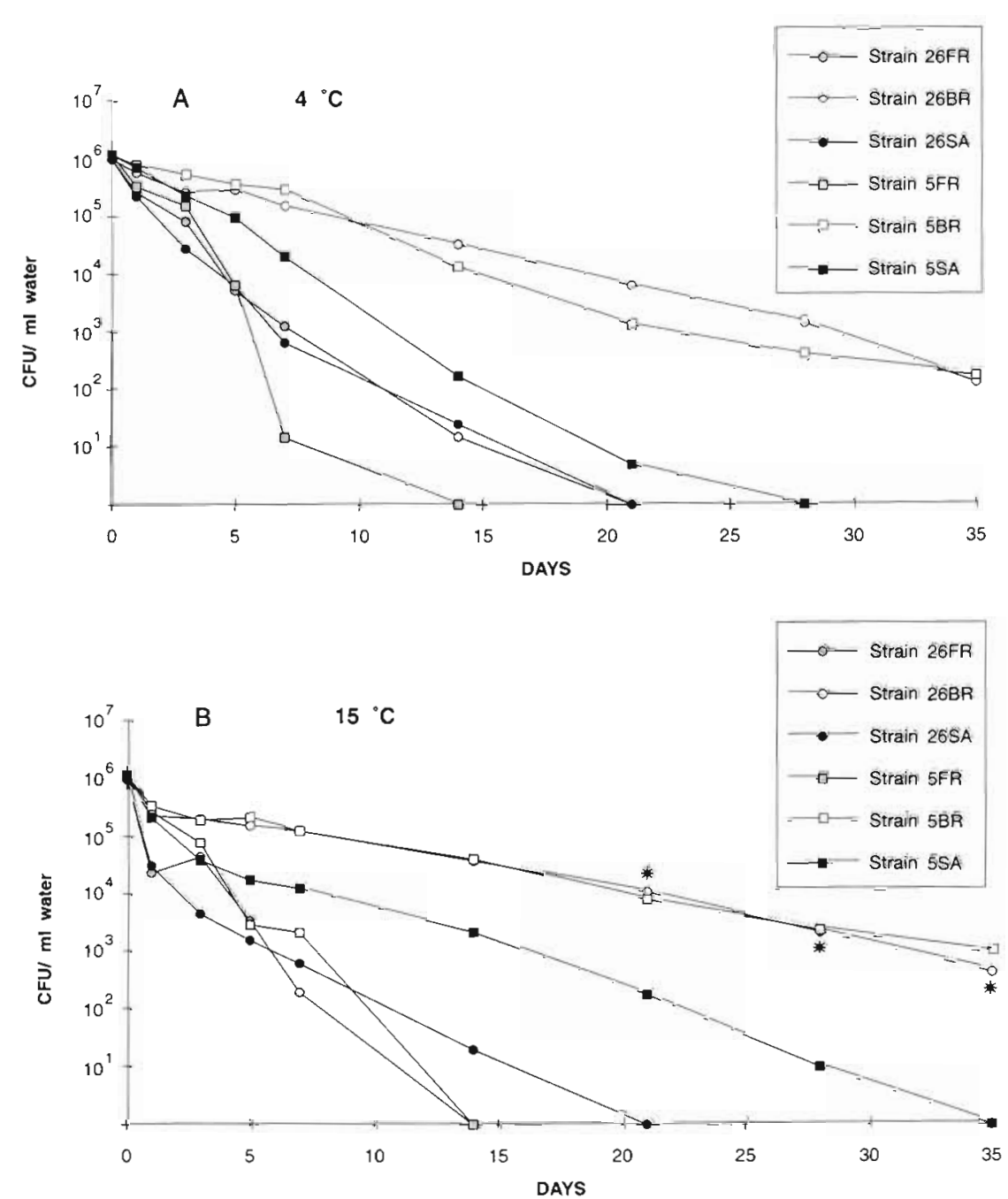

\section{DISCUSSION}

This study clearly demonstrates that the viability of the 2 'atypical' Aeromonas salmonicida strains tested was affected by salinity, temperature, and the presence of sediment.

With 1 exception (Evelyn 1971) all previous reports have dealt with the survival of 'typical' Aeromonas salmonicida. A review of the survival rate of 'typical' $A$. salmonicida in water and sediment in different investigations was given by Austin \& Austin (1987). More recently, the survival of 'typical' $A$. salmonicida has been examined by Sakai (1986), Rose et al. (1990) and Morgan et al. (1991).

Most investigations have shown that Aeromonas salmonicida can survive for only short periods in enclosures containing only water of different salinities. Prolonged survival has been recorded in microcosms with sand or mud, however, the methodology based on tests using small volumes of water and sediment in micro- cosms, without any exchange of nutrients and waste products, has been criticized (Jannasch 1967). Also, the use of sterile conditions without any interaction between the tested bacteria and other bacteria or protozoan predators has been questioned (McCarthy 1977, Austin \& Austin 1987). However, Nybroe et al. (1992) have indicated that microcosms seem to be useful for studying the effect of single factors on bacterial populations.

This study shows that the strains tested had a reduced potential for survival in brackish water without sediment. Nevertheless, the survival values reported here were within the range of those previously reported for 'typical' Aeromonas salmonicida (reviewed by Austin \& Austin 1987, Rose et al. 1990, Morgan et al. 1991), and for an 'atypical' A. salmonicida strain (survived for $7 \mathrm{~d}$ ) tested in sea water (Evelyn 1971).

The survival of the strains in this study was clearly enhanced by the presence of sediment, which is in 
accordance with data previously reported for 'typical' Aeromonas salmonicida (Cornick et al. 1969. Sakai 1986). Similar investigations have not previously been reported for 'atypical' $A$. salmonicida. The present results suggest that 'atypical' $A$. salmonicida shed from the ulcers of diseased flounders may survive in the bottom sediment for a long time, before invading healthy flounders resting on or in the bottom sediment.

McCarthy (1977) examined the survival of 'typical' Aeromonas salmonicida using dialysis bags containing mud, but the experiment had to be terminated after $10 \mathrm{~d}$ due to decomposition of the bags. During that time the viable bacteria had decreased from ca $10^{9}$ to $10^{6}$ bacteria. Michel \& Dubois-Darnaudpeys (1980) found that 'typical' $A$. salmonicida could survive in sterile river mud at least up to $291 \mathrm{~d}$. In the present investigation the survival in the 'refined' sediment was lower than the survival in the 'natural' sediment, most likely due to the higher nutrient load in the 'natural' sediment. This suggests that nutrient-rich, eutrophicated environments may favor the survival of the tested pathogens in nature, thus possibly enhancing the spread of the pathogen.

The presence of solid sand particles of the 'refined' sediment significantly enhanced the survival of the tested strains. Sakai (1986) suggested that the longterm survival of 'typical' Aeromonas salmonicida is influenced by the electrostatic mechanisms between sand particles, humic acid, amino acids and the virulent bacterial cell surface.

McCarthy (1977) reported a higher survival rate for 'typical' Aeromonas Salmonicida in unsterilized brackish water than in fresh water and salt water. The experiments were performed using dialysis bags containing about $100 \mathrm{ml}$ of water at 11 to $13^{\circ} \mathrm{C}$. In the present investigation also, the survival time was extended in brackish water compared with fresh or salt water. This is also in accordance with previous observations that the optimal growth in broth of the 'atypical', cytochrome oxidase-negative $A$. salmonicida occurred in 0.5 to $2.5 \% \mathrm{NaCl}$ (Wiklund et al. 1994). This information indicates that the occurrence of the pathogen in water bodies of high or low salinities may be limited, which is in accordance with the observation that the ulcer disease of flounder occurs in high prevalences in areas with brackish water: Elbe Estuary (Möller 1990), close to drainage sluices in the Wadden Sea, Holland (Vethaak 1992), and the northern Baltic Sea (Wiklund \& Bylund 1993).

The effect of temperature was most pronounced in the experiment with microcosms containing only water. Both tested strains showed a better survival rate at $4^{\circ} \mathrm{C}$ than at $15^{\circ} \mathrm{C}$. In the experiments with sediment, however, a slightly increased survival occurred at $15^{\circ} \mathrm{C}$. This is difficult to explain. A low temperature under nutrient-deficient conditions, as in the experiment with only water, may be more favorable as this would induce decreased metabolic activity of the cells. However, in the experiments with 'refined' sediment in the present work, nutrient deficiency did not cause a better survival of the cells at the lower temperature. Cornick et al. (1969) observed that low temperature prolonged the survival of 'typical' A. salmonicida inoculated into tap water and a mixture of tap water and soil.

There is increasing evidence that viable 'typical' Aeromonas salmonicida, as well as other bacteria, can enter a non-culturable or dormant state, i.e. a state when living cells present in microcosms or nature cannot be cultured on standard isolation media (Morgan et al. 1991). Allen-Austin et al. (1984) suggested that dormant $A$. salmonicida cells may be reactivated by the addition of nutrients. However, their results, as pointed out by Rose et al. (1990), could have been due to the presence of small numbers of viable cells in the microcosms which were not detected by the plating procedure used. The point made by Rose et al. (1990) was also demonstrated in the present work. When bacteria could no longer be detected with the plate or broth culture method in this study, the addition of nutrients to the microcosms did not resuscitate putative nonculturable or dormant cells. This indicates that any such cells were either dead or incapable of being resuscitated by the addition of nutrients. The significance of non-culturable cells in disease outbreaks has been questioned and re-infection of fish with nonculturable 'typical' $A$. salmonicida cells has not been demonstrated (Rose et al. 1990, Morgan et al. 1991).

My results suggest that the 'atypical', oxidase-negative Aeromonas salmonicida isolated from ulcerated flounder can survive in sterile sediment for a fairly long time, but only for a short time in the water column. Thus the sediment can act as a reservoir for this pathogen and facilitate the spread of the disease. Under natural conditions, the bacteria are most likely shed from the ulcers of the flounders to the sediment. The short survival time in water suggests that the tested bacteria do not constitute a part of the normal bacterial flora of the water.

Although there are several reports dealing with the survival of Aeromonas salmonicida in water and sediment under experimental conditions, the pathogen has not been isolated from natural environments except in connection with disease outbreaks in fish farms or during infection experiments (Enger et al. 1992). The reason for this might be the lack of sensitivity of the methods used and lack of selective culture media. More sensitive methods like the polymerase chain reaction may perhaps reveal the significance of 'free-living' bacterial cells in the epizootiology of $A$. salmonicida. 
Acknowledgements. I thank Mikael Enberg, Sonja Salovius, and Chira Stolpe for technical assistance and Inger Dalsgaard. and Göran Bylund for comments on the manuscript.

\section{LITERATURE CITED}

Allen-Austin D, Austin B, Colwell RR (1984) Survival of Acromonas salmonicida in river water. FEMS Microbiol Lett 21:143-146

Austin B. Austin DA (1987) Bacterial fish pathogens: disease in farmed and wild fish. Ellis Horwood, Chichester

Böhm KH, Fuhrmann H, Schlotfeldt HJ, Korting W (1986) Aeromonas salmonicida from salmonids and cyprinids serological and cultural identification. $J$ vet Med B33: $777-783$

Bootsma R, Fijan N, Blommaert J (1977) Isolation and preliminary identification of the causative agent of carp erythrodermatitis. Vet Arh 47:291-302

Cornick JW, Chudyk RV, McDermott LA (1969) Habitat and viability studies on Aeromonas salmonicida, causative agent of furunculosis. Prog Fish Cult 31:90-93

Cornick JW, Morrison CM, Zwicker B, Shum G (1984) Atypical Aeromonas salmonicida infection in Atlantic cod, Gadus morhua L. J Fish Dis 7:495-499

Dalsgaard I. Paulsen H (1986) Atypical Aeromonas salmonicida isolated from diseased sand-eels, Ammodytes lancea (Cuvier) and Hyperoplus lanceolatus (Lesauvege). J Fish Dis 9:361-364

Enger $\varnothing$, Gunnlaugsdottir B. Thorsen BK, Hjeltnes B (1992) Infectious load of Aeromonas salmonicida subsp. salmonicida during the initial phase of a cohabitant infection experiment with Atlantic salmon, Salmo salar L $J$ Fish Dis 15:425-430

Evelyn TPT (1971) An aberrant strain of the bacterial fish pathogen Aeromonas salmonicida isolated from a marine host, the sablefish (Anoplopoma fimbria), and from two species of cultured Pacific salmon. J Fish Res Bd Can 28: $1629-1634$

Jannasch HW (1967) Growth of marine bacteria at limiting concentrations of organic carbon in seawater. Limnol Oceanogr 12:264-271

Kitao T, Yoshida T, Aoki T, Fukudome M (1985) Characterization of an atypical Aeromonas salmonicida strain causing epizootic ulcer disease in cultured eel. Fish Pathol 20: $107-114$

McCarthy DH (1977) Some ecological aspects of the bacterial fish pathogen Aeromonas salmonicida. Soc appl Bacteriol. Symp Ser 6:299-324

Michel C, Dubois-Darnaudpeys A (1980) Persistence of the virulence of Aeromonas salmonicida strains kept in river

Responsible Subject Editor: T. Evelyn, Nanaimo, B.C., Canada sediments. Ann Rech vét 11:375-380

Möller H (1990) Association between diseases of flounder (Platichthys flesus) and environmental conditions in the Elbe estuary, FRG. J Cons int Explor Mer 46:187-199

Morgan JAW, Cranwell PA, Pickup RW (1991) Survival of Aeromonas salmonicida in lake water Appl environ Microbiol 57:1777-1782

Nybroe O, Christoffersen K, Riemann B (1992) Survival of Bacillus licheniformis in seawater model ecosystems. Appl environ Microbılol 58:252-259

Ohtsuka H, Nakai T, Muroga K, Jo Y (1984) Atypical Aeromonas salmonicida isolated from diseased eels. Fish Pathol 19:101-107

Plumb JA, Quinlan EE (1986) Survival of Edwardsiella ictaluri in pond water and bottom mud. Prog Fish Cult 48 $212-214$

Rose A.S, Ellis AE, Munro ALS (1990) The survival of Aeromonas salmonicida subsp. salmonicida in sea water. J Fish Dis 13:205-214

Sakai DK (1986) Electrostatic mechanism of survival of virulent Aeromonas salmonicida strains in river water. Appl environ Microbiol 51:1343-1349

Shotts EB Jr, Talkington FD, Elliott DG, McCarthy DH (1980) Aetiology of an ulcerative disease in goldfish, Carassius auratus (L.): characterization of the causative agent. J Fish Dis 3:181-186

Traxler GS, Bell GR (1988) Pathogens associated with impounded Pacific herring Clupea harengus pallasi, with emphasis on viral erythrocytic necrosis (VEN) and atypical Aeromonas salmonicida. Dis aquat Org 5:93-100

Vethaak AD (1992) Diseases of flounder (Platichthys flesus L.) in the Dutch Wadden Sea, and therr relation to stress factors. Neth J Sea Res 29:257-272

Wichardt UP, Johansson N, L.jungberg O (1989) Occurrence and distribution of Aeromonas salmonicida infections on Swedish fish farms, 1951-1987 J aquat Anim. Health 1. $187-196$

Wiklund T (1990) Atypical Aeromonas salmonicida isolated from ulcers of pike, Esox lucius L. J Fish Dis 13:541-544

Wiklund T, Bylund G (1991) A cytochrome oxidase negative bacterium (presumptively an atypical Aeromonas salmonicida) isolated from ulcerated flounders (Platichthys flesus (L.)) in the northern Baltic Sea. Bull Eur Ass Fish Pathol 11:74-76

Wiklund T, Bylund G (1993) Skin ulcer disease of flounder Platichthys flesus in the northern Baltic Sea. Dis aquat Org $17: 165-174$

Wiklund T, Dalsgaard I, Eerola E, Olivier G (1994) Characteristics of 'atypical' cytochrome oxidase-negative Aeromonas salmonicida isolated from ulcerated flounders (Platichthys flesus (L.)). J appl Bacteriol 76:511-520

Manuscript first received: April 5, 1994

Revised version accepted: October 26, 1994 